\title{
What limits bacterial production in the suboxic region of permanently ice-covered Lake Bonney, Antarctica?
}

\author{
B. B. Ward ${ }^{1, *}$, J. Granger ${ }^{1,3}$, M. T. Maldonado ${ }^{2,3}$, M. L. Wells ${ }^{2}$ \\ ${ }^{1}$ Department of Geosciences, Guyot Hall , Princeton University, Princeton, New Jersey 08544, USA \\ ${ }^{2}$ School of Marine Sciences, Libby Hall, University of Maine, Orono, Maine 04469, USA \\ ${ }^{3}$ Present address: Department of Earth and Ocean Sciences, Biological Sciences Bldg, University of British Columbia, \\ Vancouver, British Columbia V6T 1Z4, Canada
}

\begin{abstract}
Bacterial production assays (thymidine incorporation rates) were used to evaluate the activity of heterotrophic bacteria at the chemocline region in both the East (ELB) and West (WLB) Lobes of permanently ice-covered Lake Bonney, in the Taylor Valley of Antarctica. The magnitude of activity varied dramatically within the depth interval of 1 to $2 \mathrm{~m}$ from moderate to very low levels below the chemocline, especially in the East Lobe, where chemical distributions indicate the absence of a normally functioning nitrogen cycle. Several parameters (e.g. addition of nutrients or chelators, dilution) were manipulated in incubation experiments in order to identify factors that would enhance activity in the suboxic deep waters of the East Lobe. Activity, in terms of thymidine incorporation, was consistently detected in the deep-water communities, implying that, although the water may be 'toxic', the cells remain viable. None of the treatments resulted in consistent enhancement of thymidine incorporation rates in samples from below the chemocline. Bacterial populations above the chemocline appear to be phosphorus-limited. The nature of the limitation, toxicity or inhibition that limits bacterial activity in the suboxic waters has not been identified.
\end{abstract}

KEY WORDS: Antarctica - Metal chelators - Trace metals · Bacteria - Thymidine incorporation · Lake Bonney

\section{INTRODUCTION}

Lake Bonney, Antarctica, is a permanently icecovered lake in the Taylor Valley of East Antarctica $\left(77^{\circ} \mathrm{S}, 168^{\circ} \mathrm{W}\right)$. It has been thoroughly characterized in terms of its biology and physical characteristics (Priscu \& Spigel 1998) and is included in an ongoing LongTerm Ecological Research (LTER) program in the McMurdo Dry Valleys. Lake Bonney has 2 lobes, each about $40 \mathrm{~m}$ deep, separated by a narrow passage with a sill depth of 12 to $13 \mathrm{~m}$. Thus, the surface waters of the 2 lobes are able to exchange, and the circulation has been described as a set of linked gyres (Priscu \& Spigel 1998). Water enters the system at the foot of the Taylor Glacier in the West Lobe and exits at the east end of the East Lobe or is lost through sublimation of the ice surface. The chemocline depth in both lobes is deeper than the sill depth, so there is no communication of the deep waters between the 2 lobes. The water below chemocline depth in both lobes is suboxic to anoxic, and early reports documented high concentrations of bioactive and other trace metals in the hypolimnion (Boswell et al. 1967a,b, Weand et al. 1976). The most peculiar feature of the lake is the chemistry in the deep water, which is substantially different between the 2 lobes, both in total salt content and in concentration and distribution of several inorganic nitrogen species (Priscu 1995, Lyons et al. 2000).

The recent geochemical history of the lake at least partially explains the high salt and metal concentra- 
tions. There is evidence that the geologic history of the East (ELB) and West (WLB) Lobes of Lake Bonney differ significantly (Lyons et al. 1998). Oxygen and deuterium isotopic measurements in lake waters of the Dry Valleys indicate a climate shift in this region from 'warm-wet' to 'cold-dry' conditions $\sim 3000$ yr ago. As a consequence, the East and West Lobes of Lake Bonney became hydrologically separated at the sill as the 'cold-dry' conditions increased the net evaporation. While freshwater inflows from Taylor Glacier apparently sufficed to maintain ice-cover on the West Lobe (B. Lyons pers. comm.), sublimation loss quickly transformed the East Lobe into an exposed, hypersaline lake. These conditions persisted for more than a millennium until climatic conditions became warmer $\sim 1000 \mathrm{yr}$ ago. The increased freshwater inflows from the Taylor Glacier then raised the West Lobe level until freshwater flow over the sill capped the hypersaline East Lobe. Thus, the deep-water chemical distributions in the East Lobe represent the partial dilution of the old deep brine layer into the overlying fresh layer. Although sulfate is a major ion in both lobes, and oxygen is greatly depleted in the hypolimnion of both lobes, detection of hydrogen sulfide has never been reported for either lobe.

In the West Lobe of Lake Bonney, the chemocline occurs at about 15 to $17 \mathrm{~m}$, and oxygen is depleted below that depth. Ammonium accumulates to a maximum of $300 \mu \mathrm{M}$ in the deep water, and nitrate and nitrite both show small maxima ( 25 and $<1 \mu \mathrm{M}$, respectively) in the region of the chemocline. Nitrous oxide is present at relatively low levels, again with a small maximum (about $1 \mu \mathrm{M}$ ) near the chemocline (Priscu et al. 1996, Ward \& Priscu 1997, Voytek et al. 1999). In the East Lobe, oxygen is depleted below 18 to $20 \mathrm{~m}$, and ammonium accumulates to a maximum of about $150 \mu \mathrm{M}$ in the deep water. In contrast to the West Lobe, however, nitrate and nitrite both accumulate in the deep water, reaching maximum total concentrations of nearly 200 and $40 \mu \mathrm{M}$, respectively. Nitrous oxide shows a recordbreaking maximum near the chemocline of about $40 \mu \mathrm{M}$ (Priscu et al. 1996). Clearly, the nitrogen cycle of the East Lobe is unusual for a stratified aquatic system; suboxic conditions in both lobes would be expected to result in denitrification and subsequent depletion of nitrogen oxides. The different nitrogen distributions have been interpreted to infer that denitrification occurs in the West Lobe but not in the East. Priscu (1997) has demonstrated that denitrification can be detected in the West Lobe but not in the East Lobe.

The McMurdo LTER project (see huey.colorado. edu/LTER) has reported bacterial abundance and production rates in depth profiles from central stations in both lobes of Lake Bonney for many years. The longrunning time series of bacterial production measure- ments shows interannual variability in bacterial parameters; however, a seasonal cycle generally exhibits increased abundances and productivity in November and December (Takacs \& Priscu 1998). In the West Lobe, the bacterial abundance maximum (15 to $16 \mathrm{~m}$ ) usually coincides in depth with the productivity maximum, but in the East Lobe, a strong abundance maximum at 20 to $25 \mathrm{~m}$ is consistently deeper than the productivity maximum at 12 to $15 \mathrm{~m}$ (Takacs \& Priscu 1998). The productivity data consistently show detectable bacterial activity in and below the chemocline of the West Lobe but more rarely and at very low levels at analogous depths in the East Lobe.

The reason for the collapse of the nitrogen cycle in the East Lobe could be specific to some process, i.e. denitrification, in the nitrogen cycle itself, or it could be due to overall limitation, toxicity or inhibition of essentially all microbial activity in the water. The potential for specific inhibition of denitrification is addressed separately (authors' unpubl.). The LTER data suggest that overall bacterial activity is repressed in the subchemocline waters of the East Lobe. Here, we report on the results of experiments designed to determine which aspects of the lake water chemistry could be responsible for a nearly complete suppression of bacterial activity. We hypothesized that the region below the chemocline in the East Lobe was essentially a dead zone, with no detectable microbial activity, possibly due to toxicity of high concentrations of bioactive metals, such as copper, lead, nickel or cadmium. The hypothesis was addressed by measuring bacterial production, as estimated by thymidine incorporation rates, at discrete depths near the chemocline in both lobes of the lake as well as in many experiments focused in the deep waters of the East Lobe. Manipulations, such as organic carbon or phosphorus additions, and dilution of the salt and metal content of the deep waters, were performed. The experiments focused in particular on a potential role for bioactive metals (e.g. metals required as cofactors in enzymes or those which cause toxicity by various mechanisms) and their availability or limitation. The concentrations and availability of metals were manipulated using chelation with organic chelators of varying specificities. Thymidine incorporation rates were measured to assess the effect of the manipulations on bacterial growth in lake water.

\section{MATERIALS AND METHODS}

Sample collection. Two stations, one near the center of each lobe, were sampled at several depths for nutrient profiles and at 1 or 2 depths each for incubation experiments. We have summarized some of the chemical characteristics of the 2 lobes (Table 1). Based on 
previously reported chemical profiles, $16 \mathrm{~m}$ in the West Lobe and $22 \mathrm{~m}$ in the East Lobe were identified as the location in the chemocline chemical gradient, where denitrification was expected to occur. These depths were just below the depth where oxygen concentrations begin to decrease dramatically to nearly undetectable levels (Ward \& Priscu 1997) and where ammonium concentrations begin to increase. This is the depth horizon where denitrification is implicated by nutrient profiles in the West Lobe and where denitrification was actually detected previously (Priscu 1997). A comparison depth above the chemocline, 19 m, was sampled in the East Lobe.

Water was collected from Lake Bonney using trace metal clean techniques. A peristaltic pump equipped with acid-leached C-Flex tubing (Cole Parmer) was used to pump water from depth through an acid cleaned teflon (PFA) tube which was lowered through a hole drilled through the $4 \mathrm{~m}$ thick permanent ice cover. Water exited the sampling tube inside a Plexiglas positive pressure hood supplied with HEPA (High Energy Particulate Air) filtered air. All sample handling was done with gloved hands by workers wearing clean disposable lab coats, using protocols developed for the collections of offshore seawaters (Bruland et al. 1979). After the end of the tube was positioned at the sampling depth (determined by deployment on a metered line weighted with a sealed plastic bottle filled with sand), $10 \mathrm{l}$ of water was pumped and discarded, in order to flush the tubing. Sampling always proceeded from shallow to deeper depths to avoid contaminating the tubing with the higher salt and metal content of the deeper layers. The sample line was cleaned between each deployment by recirculating with detergent (Micro), soaking (>12 h) with $6 \mathrm{~N} \mathrm{HCl}$ (Fisher TM grade), followed by a thorough rinse with deionized (Nanopure) water.

Polyethylene-lined trilaminate bags (Pollution Measurement) were used for sample collection and incubation. The bags were composed of a laminate including an outer layer of polyester, a middle layer of aluminum foil and an inner layer of low-density polyethylene (125 $\mu$ l) (Pollution Measurement). Before use, the bags were cleaned by multiple rinses with $10 \% \mathrm{HCL}$ and Milli-Q water. Exposure to strong acid for more than $1 \mathrm{~h}$ was found to compromise the gas impermeability of the bags, so multiple shorter rinses were used instead. The deep lake water was supersaturated with carbon dioxide. Therefore, the sample water was passed through a debubbler (a plastic bottle in which the gases released by decreased pressure were collected into the headspace) to avoid creating a headspace in the incubation bags. The water was pumped directly into previously cleaned bags of approximately $500 \mathrm{ml}$ maximum volume $(12.5 \times 20 \mathrm{~cm})$ through the bag opening, a $10 \mathrm{~cm}$ length of $0.312 \mathrm{~cm}$ diameter hard polypropylene tubing. The bags were closed with plastic 3-way stopcocks and placed in insulated boxes for return to the laboratory by helicopter (maximum $4 \mathrm{~h}$ delay).

Experimental manipulations. In the laboratory, the bags were weighed and sample masses were all set to $400 \mathrm{~g}(\sim 400 \mathrm{ml})$ by removing any excess water with an acid cleaned syringe. Bags were incubated in a $12^{\circ} \mathrm{C}$ dark incubator, $12^{\circ} \mathrm{C}$ having been previously determined to be the optimal growth temperature for several bacterial cultures isolated from this lake (Ward \& Priscu 1997). After equilibration (usually overnight), additions were made to the bags to affect various treatments. All solutions were made up in Milli-Q water (MQ), with contaminant metals being removed by ion exchange (Chelex-100) if necessary (Price et al. 1988/1989), and all additions were made with acidcleaned plastic syringes. Treatments included the following:

Chelator additions: If concentrations of bioactive trace metals were sufficiently high in natural lake waters to cause toxicity, the addition of chelators could alter their speciation, to reduce their availability and toxicity. Reagent grade desferrioxamine $\mathrm{B}(\mathrm{DFB} ; 1$ to $5 \mu \mathrm{M})$, ethylendiaminetetraacetic acid (EDTA; 1 to

Table 1. Chemistry of Lake Bonney. Data were collected on 3 (East Lobe Lake Bonney, ELB) and 5 December 1999 (West Lobe Lake Bonney, WLB) by the McMurdo LTER team (http://huey.colorado.edu/LTER)

\begin{tabular}{|c|c|c|c|c|c|c|c|c|c|c|c|c|c|c|c|c|}
\hline \multirow{2}{*}{$\begin{array}{l}\text { Depth } \\
\text { (m) }\end{array}$} & \multicolumn{2}{|c|}{$\mathrm{pH}$} & \multicolumn{2}{|c|}{$\mathrm{DIC}\left(\mathrm{mg} \mathrm{l}^{-1}\right)$} & \multicolumn{2}{|c|}{$\mathrm{Na}\left(\mathrm{mg} \mathrm{l}^{-1}\right)$} & \multicolumn{2}{|c|}{$\mathrm{Cl}\left(\mathrm{mg} \mathrm{l}^{-1}\right)$} & \multicolumn{2}{|c|}{$\operatorname{Mg}\left(\mathrm{mg} \mathrm{l}^{-1}\right)$} & \multicolumn{2}{|c|}{$\mathrm{SO}_{4}\left(\mathrm{mg} \mathrm{l}^{-1}\right)$} & \multicolumn{2}{|c|}{$\mathrm{K}\left(\mathrm{mg} \mathrm{l}^{-1}\right)$} & \multicolumn{2}{|c|}{$\mathrm{Ca}\left(\mathrm{mg} \mathrm{l}^{-1}\right)$} \\
\hline & ELB & WLB & ELB & WLB & ELB & WLB & ELB & WLB & ELB & WLB & ELB & WLB & ELB & WLB & ELB & WLB \\
\hline 5 & 8.6 & 8.7 & 23.5 & 20.6 & 19. & 48 & 897 & 90 & 77 & 74 & 231 & 22 & 23.9 & 23.7 & 96 & 95 \\
\hline 10 & 8.3 & 8.3 & 30.2 & 25.5 & 40.9 & 880 & 1993 & 2220 & 171 & 145 & 243 & 256 & 51.1 & 39.8 & 114 & 114 \\
\hline 15 & 6.7 & 6.2 & 151 & 53 & 263 & 21444 & 15551 & 569 & 17 & 50 & 965 & 4 & 308 & 701 & 473 & 1700 \\
\hline 20 & 6.3 & 5. & 226 & 69 & 971 & 282 & 88313 & 4 & 17 & 6 & 33 & 0 & 67 & 982 & 1133 & 2001 \\
\hline 25 & 6.3 & 5.8 & 141 & 85 & 2014 & 33 & 15 & 77 & & 7 & 8 & & 88 & 37 & 1430 & 1977 \\
\hline 30 & 6.1 & 5.7 & 63.0 & 90 & 2015 & 38077 & 169593 & 85332 & 316 & 92 & 30 & & 2962 & 1321 & 1576 & 2233 \\
\hline 35 & 6.8 & 5.8 & 58.7 & 89 & 2175 & 39133 & 175945 & 86257 & 32375 & 92 & 3459 & & 3030 & 1355 & 1569 & 2259 \\
\hline $37 / 38.5$ & 6.7 & 5.9 & 66.0 & 918 & 3128 & 40361 & 187231 & 87250 & 26292 & 9526 & 3509 & 4832 & 2466 & 1377 & 1331 & 2281 \\
\hline
\end{tabular}


$100 \mu \mathrm{M})$, diethylenetriaminepentaacetic acid (DTPA; 0.75 to $100 \mu \mathrm{M}$ ), diethyldithio-carbamate (DDC; 10 to $100 \mu \mathrm{M})$, and humic acids (Sigma) ( $\mathrm{HA}_{;} 32 \mathrm{mg} \mathrm{l}^{-1}$ ) were added at various concentrations to separate treatments (noted in 'Results' where appropriate). DFB differs from the other chelators in that it is a siderophore isolated from terrestrial fungus and is highly specific for iron relative to other metals. At least 1 marine bacterium has been found to produce a derivative of ferrioxamine (Martinez et al. 2001) and it can facilitate iron uptake by some non-DFB-producing strains (Granger \& Price 1999). Because siderophores are used as competitive tools among bacteria to acquire iron, DFB might increase or decrease iron availability depending on whether Lake Bonney microbes are able to use this form of iron. By contrast, DDC, EDTA and DTPA are synthetic, more general, metal chelators, having a range of affinities for different bioactive metals. These compounds are routinely used in culturing microbes and testing for metal requirements in enzymes (e.g. Coyne et al. 1989, Sillanpaa \& Aimo 1996). HAs are natural metal-complexing compounds found in normal lake systems having comparatively low affinities for trace metals in high ionic strength solutions. If some of the metals are present at toxic levels, then chelation by these 'generalist' chelators might reduce metal activity and thus allow growth.

Organic substrate additions: Additions of organic carbon had been found to increase denitrification rates in the West Lobe of Lake Bonney (Priscu 1997). If carbon substrate concentrations were limiting to bacterial growth, then additional substrate might enhance thymidine incorporation rates. Acetate $(52.5 \mu \mathrm{M}$, a concentration equivalent to the acetate component of the addition of $7.5 \mu \mathrm{M}$ DTPA), bactopeptone (200 mg $\mathrm{l}^{-1}$, the level used for cultivation of lake isolates) and culture filtrate (see below) were added as noted in individual experiments described below.

Inorganic nutrient additions: The phytoplankton in several of the Taylor Valley lakes, including Lake Bonney, are reportedly phosphorus-limited (Dore \& Priscu 2001), and denitrification is often nitrate-limited in aquatic and sediment environments. Therefore, inorganic nutrient additions were tested for their ability to enhance bacterial activity. Nitrate $(50 \mu \mathrm{M}$, the level observed at $22 \mathrm{~m}$ in the East Lobe) was added to circumvent potential limitation of denitrification by nitrate in dilution experiments (see below), assuming that most cells present in the suboxic water would be capable of denitrification. Phosphate $(10 \mu \mathrm{M})$ was added to test for phosphate limitation of overall bacterial activity.

Dilution experiments: Dilution was intended to dilute either metals or salts, or both, thus reducing potential metal or salt toxicity (previous work showed that a slightly lower than ambient salinity was optimal for growth of isolates from below the chemocline). Dilution of sample water was accomplished by adding $\mathrm{MQ}$ or artificial lake water (ALW) to the samples in ratios representing up to 10 -fold dilution. ALW was made up at a salinity of 80 , and the major ion composition was adjusted according to the major ion composition of the water in each lobe (Lyons et al. 2000). The same overall salt concentration was used in both ELB and WLB experiments, because it was clear that denitrification and growth were possible at the salinity of the West Lobe (80), and also that cultivated organisms from both lobes had salinity optima much lower than that found at $22 \mathrm{~m}$ in the East Lobe (135). For ELB, the composition of ALW was the following: $35 \mathrm{~g} \mathrm{NaCl}$, $2.9 \mathrm{~g} \mathrm{Na}_{2} \mathrm{SO}_{4}, 0.44 \mathrm{~g} \mathrm{NaHCO}_{3}, 0.49 \mathrm{~g} \mathrm{KBr}, 1.5 \mathrm{~g} \mathrm{KCl}$, $0.07 \mathrm{~g} \mathrm{H}_{3} \mathrm{BO}_{3}, 75 \mathrm{~g} \mathrm{MgCl} \cdot 6 \mathrm{H}_{2} \mathrm{O}, 3.3 \mathrm{~g} \mathrm{CaCl} \cdot 2 \mathrm{H}_{2} \mathrm{O}$, $0.04 \mathrm{~g} \mathrm{SrCl}_{2} \cdot 6 \mathrm{H}_{2} \mathrm{O}$ in $1 \mathrm{l}$ of $\mathrm{MQ}_{\text {; for } \mathrm{WLB}}$, the composition of ALW was the following: $46.7 \mathrm{~g} \mathrm{NaCl}, 2.9 \mathrm{~g}$ $\mathrm{Na}_{2} \mathrm{SO}_{4}, 0.44 \mathrm{~g} \mathrm{NaHCO}_{3}, 0.48 \mathrm{~g} \mathrm{KBr}, 1.5 \mathrm{~g} \mathrm{KCl}, 0.06 \mathrm{~g}$ $\mathrm{H}_{3} \mathrm{BO}_{3}, 55 \mathrm{~g} \mathrm{MgCl}_{2} \cdot 6 \mathrm{H}_{2} \mathrm{O}, 2.51 \mathrm{~g} \mathrm{CaCl}_{2} \cdot 2 \mathrm{H}_{2} \mathrm{O}, 0.04 \mathrm{~g}$ $\mathrm{SrCl}_{2} \cdot 6 \mathrm{H}_{2} \mathrm{O}$ in $1 \mathrm{l}$ of MQ. Metal contaminants in these solutions were removed by ion exchange with Chelex 100 (Price et al. 1988/1989). Dilution with ALW was designed to remove the metal component of the solutes without changing the salinity dramatically. In some experiments, lake water was filtered $(0.2 \mu \mathrm{m})$ through acid-cleaned polyethylene cartridge filters to remove particle interactions.

Live bacterial cultures (CB): Most of the above manipulations were repeated with the addition of live bacteria to the incubations. If the addition of live bacteria to the experimental bags caused an increase in the thymidine incorporation rate relative to the parallel experiments without CB additions, it would imply that the lake water was not completely inhibitory to growth. The denitrifying bacterial strains WLB20 and ELB17, which were isolated from the West Lobe and East Lobe of Lake Bonney, respectively, in 1992, both have a temperature optimum of 12 to $15^{\circ} \mathrm{C}$ and a salinity optimum of $\sim 35$ (Ward \& Priscu 1997). They were cultured at $12^{\circ} \mathrm{C}$ in filtered seawater amended with $0.2 \mathrm{~g} \mathrm{l}^{-1}$ bactopeptone and $50 \mu \mathrm{M}$ nitrate in the laboratory in the same bags used for experimental incubations. Cultured bacteria (CB) were added to the treatment bags at a final concentration of approximately $10^{5} \mathrm{ml}^{-1}$. The inoculum consisted of approximately equal numbers of the 2 denitrifying strains, ELB17 and WBL20. The abundance of CB in the experimental incubations was determined by indirect immunofluorescence staining and epifluorescence microscopy (see below; Ward \& Priscu 1997) of subsamples collected from the incubation bags.

Incubation experiments and thymidine incorporation measurements. Bags containing the treated 
samples were incubated at $12^{\circ} \mathrm{C}$ for up to $2 \mathrm{wk}$. At intervals, subsamples were removed and used in shortterm thymidine uptake experiments. In 1999, duplicate subsamples $(20 \mathrm{ml})$ were incubated in glass scintillation vials at $12^{\circ} \mathrm{C}$ for up to $4 \mathrm{~h}$. In 2000 , duplicate subsamples $(20 \mathrm{ml})$ were incubated for $24 \mathrm{~h}$ in polypropylene tubes inside a glove box filled with $\mathrm{N}_{2}$ in a $12^{\circ} \mathrm{C}$ cold room. In 2000, all sample transfers and manipulations were performed in the glove box so that the samples were never exposed to air. The longer incubation time in 2000 was intended to enhance sensitivity, and the glove box allowed the sample to remain suboxic under conditions similar to in situ conditions. This glove box was not available for the 1999 field season, so oxygenation of the samples undoubtedly occurred to some degree. Assuming at least some of the organisms present were denitrifiers, addition of oxygen should not have been toxic and may in fact have enhanced thymidine incorporation capability of the sample.

${ }^{3} \mathrm{H}$-thymidine (ring-labeled), diluted in $\mathrm{MQ}$, was added at approximately $1.7 \mu \mathrm{Ci}$ per $20 \mathrm{ml}$ subsample (20 nM final concentration). Formalin (1\% final concentration) was added to blank incubations. The incubations were stopped by the addition of cold TCA, and the filtration and quantification followed standard methods (Bell 1993). Each treatment was performed in duplicate (2 bags), and duplicate samples from each bag were used in thymidine incorporation experiments. Results are presented as the average and SD of $4 \mathrm{dpm}$ determinations per treatment. Small sample sizes and limited replication may weaken the robustness of our statistical comparisons; we infer that 2 results are significantly different if their SD do not overlap. A thymidine incorporation rate less than 0 indicates that the magnitude of the formalin blank exceeded that of the experimental treatment. The experimental design included independent replication of treatments in separate experiments on water collected from the same depths but manipulated in the laboratory on separate days. This provides a check on consistency in the absence of true replication.

In describing the results, we focus on 3 indications of activity in the incubation experiments. 'Activity' is defined as uptake of thymidine, at a minimum of 1 time point in the controls or treatments, that is significantly greater than 0 (i.e. significantly greater than in the formalin-killed blanks). In the case of controls (no amendments to natural lake water), this activity might increase with time due to enhanced growth related to bottle effects (e.g. diminished activity of grazers in oxic samples) or may remain constant over time (i.e. the community remains in steady state). 'Growth' implies a statistically significant, consistent increase in thymidine incorporation rate over at least 2 time points.
However, in cases where the initial activity in a treatment is lower than in the relevant control ('inhibition'), any subsequent 'growth' is interpreted as a 'recovery' from the chemical insult. The data are presented in terms of dpm $\mathrm{h}^{-1}$ with the formalin-killed blank values subtracted. Results are discussed by grouping experiments that received similar treatments. However, similar treatments on different dates cannot always be compared quantitatively because slight differences in sampling depth could have introduced differences in initial conditions. Data have not been converted to units of carbon or cell biomass production because the comparisons we wish to make are between treatments, not between rates measured here and other published data. Nor do we wish to assess the contribution of these processes to the carbon cycle of the environment in these experiments, which could only be done after extensive calibration in additional experiments.

Chemical and microbiological analyses. Nutrient measurements were made by autoanalyzer (Lachat Instruments) on filtered samples stored frozen for up to 4 wk. Oxygen concentrations in the incubation bags were measured using the micro-Winkler colorimetric method (Broenkow \& Cline 1969) and nitrite by the azo-dye colorimetric method (Parsons et al. 1984). Oxygen measurements were made on duplicate bags that were incubated in parallel to monitor for leakage. No significant increases in oxygen concentration were detected in any bags measured for up to $2 \mathrm{wk}$, but it cannot be guaranteed that none of the actual incubation bags leaked. Indirect immunofluorescence (IIF) enumeration of the cultivated Lake Bonney denitrifying strains was performed as described previously (Ward \& Carlucci 1985, Ward \& Priscu 1997). Samples were viewed by epifluorescence microscopy at $1000 \times$ power using a Zeiss standard microscope with epifluorescence modification (50 W Hg illumination; $450 \mathrm{DF}$ 55 filter for excitation, 505 DF 35 barrier filter and 505DRLEXT02 dichroic filter). Acridine orangestained filters were prepared from 5 to $10 \mathrm{ml}$ aliquots of the samples and enumerated using the same microscope with the same filter set (Hobbie et al. 1977).

\section{RESULTS}

\section{Nutrient and metal distributions}

Distributions of nitrogen compounds in the 2 lobes of Lake Bonney were very similar to those reported previously (Ward \& Priscu 1997) and were entirely consistent with the long-running data set collected by the McMurdo Dry Valleys LTER. In brief, oxidized forms of nitrogen (nitrite and nitrate) were abundant in the suboxic water below the chemocline in the East Lobe 
(Fig. 1A) but ammonium was the only fixed nitrogen compound that was abundant in the deep water of the West Lobe (Fig. 1B). The in situ temperatures at the incubation depths were as follows: ELB $19 \mathrm{~m}, 6^{\circ} \mathrm{C}$ ELB $22 \mathrm{~m}, 5^{\circ} \mathrm{C}$; WLB $16 \mathrm{~m}, 1^{\circ} \mathrm{C}$.

Complete metal concentration and speciation data will be reported in detail elsewhere (authors' unpubl.). For the purposes of this report, a brief description of their distributions will suffice: total dissolved metals were uniformly low in the surface waters of both lobes, in the low nM range for $\mathrm{Mo}, \mathrm{Cd}, \mathrm{Pb}, \mathrm{Mn}, \mathrm{Fe}, \mathrm{Co}, \mathrm{Ni}, \mathrm{Cu}$ and $\mathrm{Zn}$. Concentrations of all these elements increased dramatically below the chemocline in both lobes (Table 2).

\section{Incubation experiments}

Results are presented separately for the West and East Lobes for 1999 and 2000. Experiments are grouped in terms of the variables manipulated in each experiment.

\section{West Lobe Lake Bonney}

Experiments in both lobes focused on the chemocline depth, where denitrification should be favored and where previous researchers had detected microbial activity reliably in the West Lobe but only sporad-

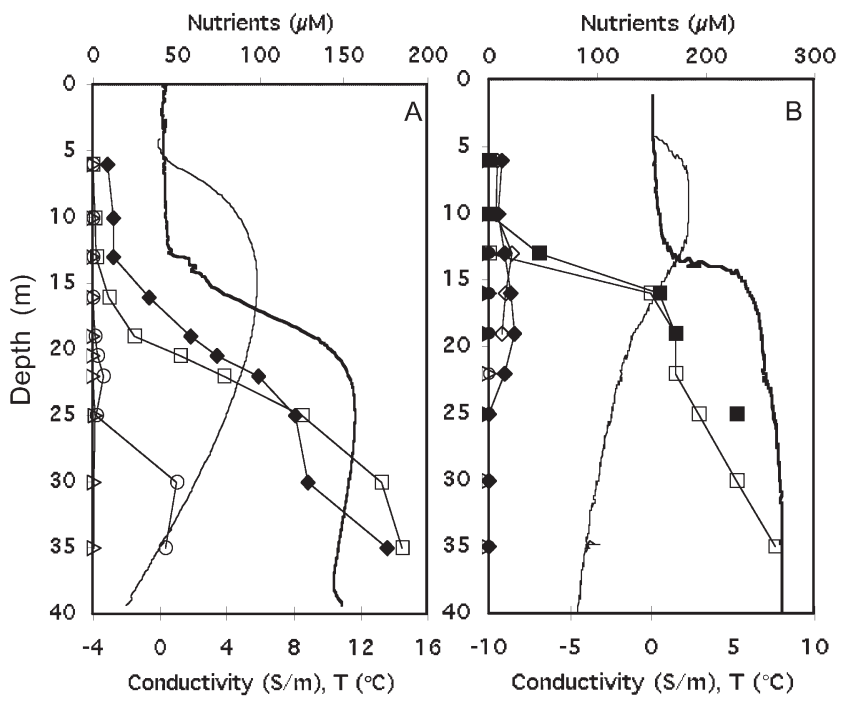

Fig. 1. Dissolved inorganic nitrogen profiles in (A) East Lobe Lake Bonney (ELB) collected in November 2000 and (B) West Lobe Lake Bonney (WLB) collected during November 1999. $\triangleright: \mathrm{PO}_{4}{ }^{3-} ; \mathrm{O}: \mathrm{NO}_{2}{ }^{-} ; \bullet: \mathrm{NO}_{3}{ }^{-}(2$ casts on separate days $) ; \mathbf{\square}, \square$ : $\mathrm{NH}_{4}{ }^{+}$(2 casts on separate days). Thick lines = conductivity; thin lines $=$ temperature. Conductivity and temperature data from 2000 ically in the East Lobe. All West Lobe experiments were performed on water collected at $16 \mathrm{~m}$ and handled as described above. The West Lobe experiments are in some sense all positive control experiments for the subsequent East Lobe experiments - the bacterial community at $16 \mathrm{~m}$ in WLB consistently shows activity in the LTER data set and in our denitrification experiments (authors' unpubl.). Their usefulness here therefore lies mainly in their comparison to the ELB experiments.

Effect of chelators. No thymidine incorporation above the formalin-treated control level in the indigenous bacteria was detected after $2 \mathrm{~h}$ incubations with added chelators (DFB at $1 \mu \mathrm{M}$, DTPA at 0.75 and $7.5 \mu \mathrm{M}$; Expt 1; data not shown). In Expt 2, those treatments were repeated with the addition of 4 parallel treatments in which live bacteria were added with the chelators. After $2 \mathrm{~h}$ incubations, significant activity was detected in all the vials to which bacteria had been added, but no activity was detected in samples containing only the indigenous community (Fig. 2). Initial activity in treatments which received added bacteria was $1000 \mathrm{dpm} \mathrm{h}^{-1}$ except the DTPA addition, where almost $2000 \mathrm{dpm} \mathrm{h}^{-1}$ were measured. Five days later, the indigenous community still showed little or no activity, while thymidine incorporation rates had increased significantly in all 4 of the treatments that received live bacteria (i.e. growth occurred). Of the treatments that were inoculated with bacterial cells, only the treatment that received 7.5 $\mu \mathrm{M}$ DTPA had sig-

Table 2. Summary of trace metal concentrations in East (ELB) and West (WLB) Lobe of Lake Bonney

\begin{tabular}{|lccr|}
\hline Metal & $\begin{array}{c}\text { Surface (10 m) } \\
\text { conc. (nM) }\end{array}$ & $\begin{array}{c}\text { Depth of max. } \\
\text { conc. (m) }\end{array}$ & $\begin{array}{c}\text { Conc. } \\
\text { at max. (nM) }\end{array}$ \\
\hline ELB & & & \\
$\mathrm{Mo}$ & 14 & 35 & 182 \\
$\mathrm{Cd}$ & 0 & 25 & 23 \\
$\mathrm{~Pb}$ & 0 & 25 & 201 \\
$\mathrm{Mn}$ & 0 & 25 & 82700 \\
$\mathrm{Fe}$ & 0 & 25 & 288 \\
$\mathrm{Co}$ & 0 & 25 & 795 \\
$\mathrm{Ni}$ & 32 & 25 & 3508 \\
$\mathrm{Cu}$ & 48 & 25 & 883 \\
$\mathrm{Zn}$ & 6 & 25 & 2350 \\
$\mathbf{W L B}$ & & & \\
$\mathrm{Mo}$ & 32 & 19 & 74 \\
$\mathrm{Cd}$ & 2.6 & 19 & 6.9 \\
$\mathrm{~Pb}$ & 0 & 35 & 54.6 \\
$\mathrm{Mn}$ & 0 & 35 & 164460 \\
$\mathrm{Fe}$ & 0 & 30 & 55452 \\
$\mathrm{Co}$ & 0 & 35 & 1147 \\
$\mathrm{Ni}$ & 47 & 35 & 2800 \\
$\mathrm{Cu}$ & 138 & 35 & 2897 \\
$\mathrm{Zn}$ & 8 & 35 & 569 \\
& & & \\
\hline
\end{tabular}




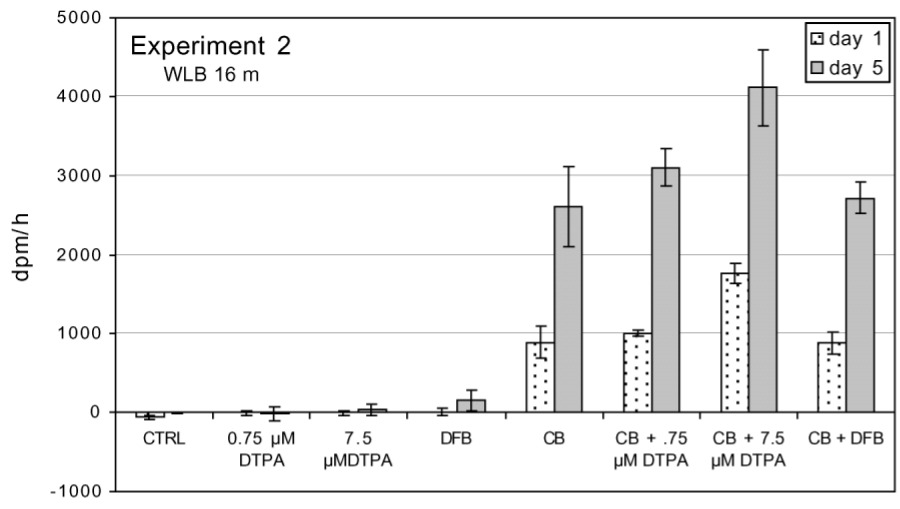

Treatment/Time (days)

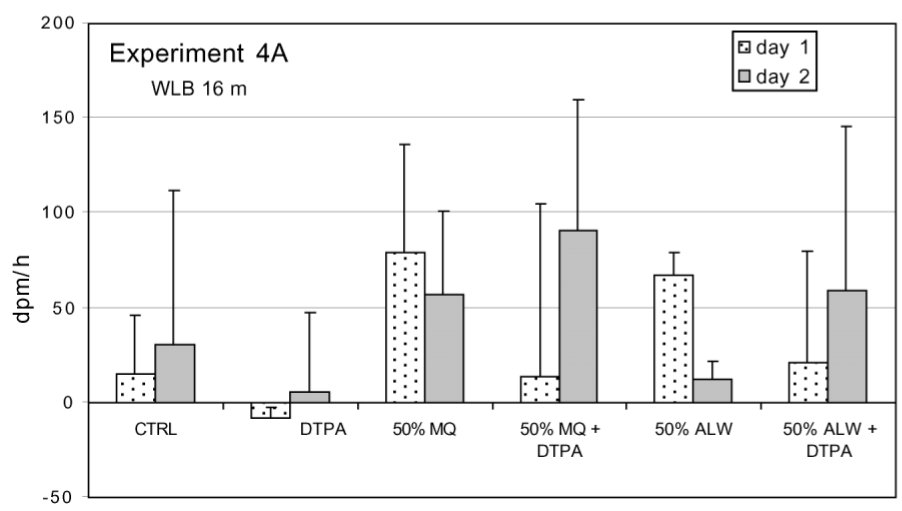

Treatment/Time (days)
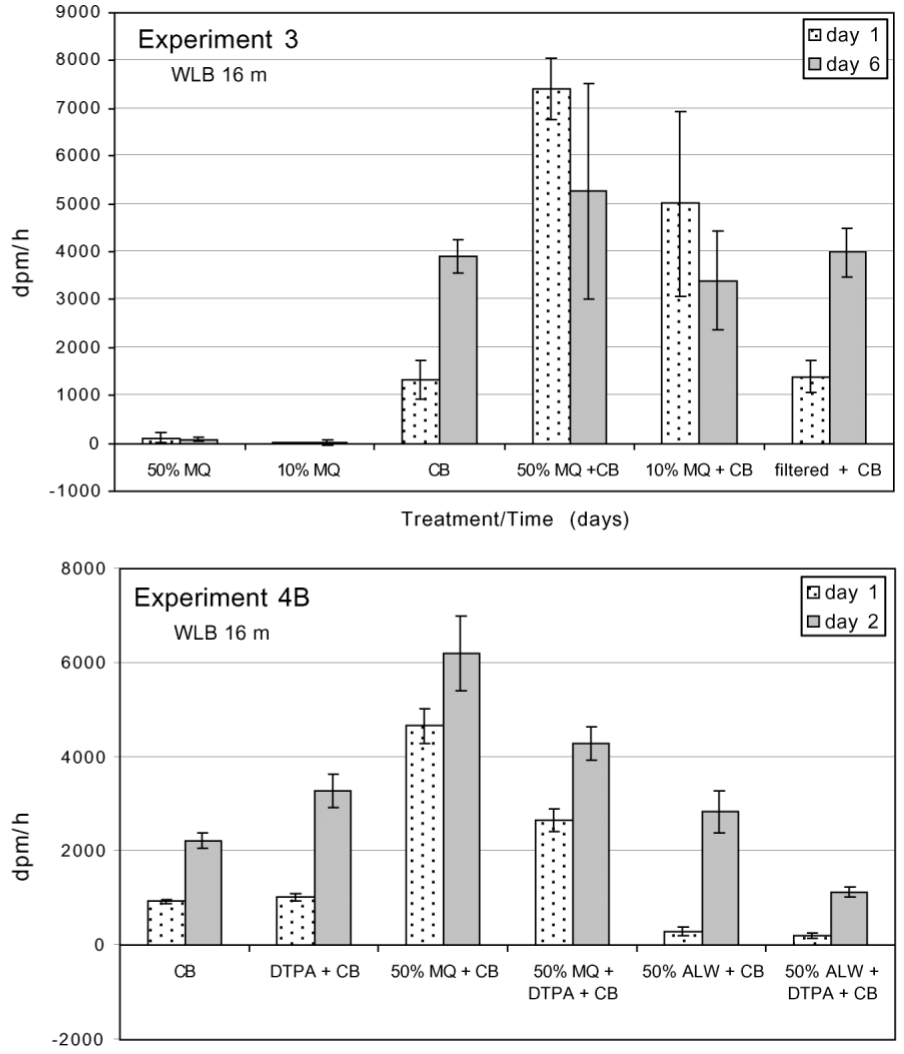

Treatment/Time (days)

Fig. 2. West Lobe Lake Bonney (WLB) experiments in 1999 with 16 m water. Bars represent mean of 4 incubations; error bars represent SD. Expt 2 (30 November 1999), effect of iron and other bioactive metals; Expt 3 (30 November 1999), effect of lake water dilution; Expt 4 (9 December 1999), effect of salinity. Expt 4A, 50\% MQ treatment = dilution with Milli-Q water and no further additions. $50 \% \mathrm{ALW}=$ dilution with chelexed artificial lake water. Expt 4B, same suite of treatments as Expt 4A except that live bacteria (CB) were added to all. DTPA concentrations were $7.5 \mu \mathrm{M}$

nificantly higher activity $\left(4000 \mathrm{dpm} \mathrm{h}^{-1}\right)$ than the sample that did not receive chelators $\left(3000 \mathrm{dpm} \mathrm{h}^{-1}\right)$.

When the inoculum of live cells was added, the growth medium in which the cells were suspended (1 to $2 \mathrm{ml}$ ) was also added. Thus, in addition to live bacteria, the CB treatments also received a minor addition of medium (1 to $2 \mathrm{ml}$ of medium diluted into $400 \mathrm{ml}$ of lake water) containing partially spent substrate and, potentially, exudates from growing cells that might enhance activity. This complication was avoided by centrifuging the cells before inoculation when similar manipulations were repeated the following year (see below).

Effect of lake water dilution. To further explore whether physical or chemical constraints were inhibiting microbial activity in WLB 16 m water, a series of dilution experiments were conducted. Dilution of West Lobe water with $\mathrm{MQ}$ resulted in minimal activity by the indigenous community (Expt 3; Fig. 2) and no additional activity was detected in the $2 \mathrm{~h}$ uptake measurements made after $6 \mathrm{~d}$ continued incubation. No control treatment was included in this experiment because no activity had been detected in the previous control treatment from the same depth (Expt 2).

In the parallel treatments to which live bacteria were added, initial thymidine incorporation rates were enhanced over the indigenous community rates, especially in the samples that had been diluted. Activity of diluted treatments was above $7000 \mathrm{dpm} \mathrm{h}^{-1}$ initially, compared to $1000 \mathrm{dpm} \mathrm{h}^{-1}$ observed for cells added to undiluted water here and in the previous experiment. After 6 d incubation, however, thymidine incorporation rates did not increase further in the diluted samples, while growth was apparent in undiluted samples to which bacteria had been added. It appears that while dilution may have increased growth, substrate limitation likely prevented sustained growth in the diluted medium. Filtered lake water to which cells were added yielded the same thymidine incorporation rate as unfiltered water, implying that all the activity we detected was due to the added cells and that particles do not inhibit activity in this community. 
Both salinity and metal concentrations were lowered by $M Q$ dilution in the above experiments, so the 2 potential effects were separated in Expt 4. Initial activity was detected only in the 2 treatments that had been diluted by $50 \%$ (1 with MQ and 1 with ALW)
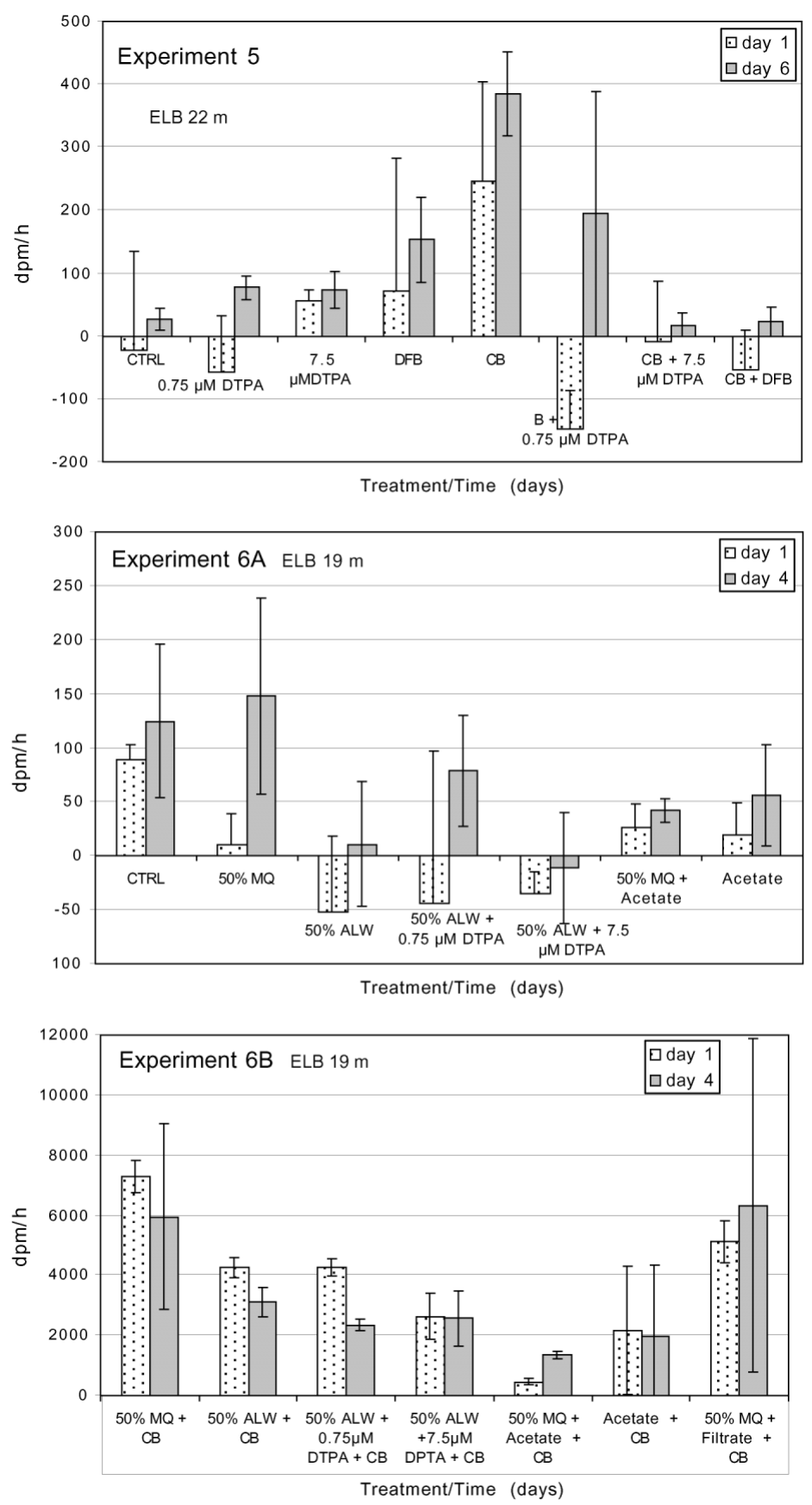

Fig. 3. East Lobe Lake Bonney (ELB) experiments in 1999. Expt 5 (22 m, 26 November 1999), effect of iron and other bioactive metals. Expt 6 (19 m, 6 December 1999), effect of dilution without (Expt 6A) and with (Expt 6B) the addition of live bacteria. DFB additions were $1 \mu \mathrm{M}$ and DTPA as shown and received no chelator additions, but growth did not occur (Expt 4A; Fig. 2). In the parallel dilution/chelator treatments to which live bacteria were added, growth occurred in all combinations, including the treatment that received only live bacteria (Expt 4B, Fig. 2). Again, a marked increase in activity was observed for the $50 \%$ dilution treatment, as in Expt 3. Dilution with ALW, however, initially had a negative effect relative to the control. There was no consistent effect of chelator addition on either initial thymidine incorporation rates or on the increase in thymidine incorporation rate after $2 \mathrm{~d}$. While DTPA addition alone increased activity of added cells, when added to MQ diluted water, the effect of DTPA was negative.

\section{East Lobe Lake Bonney 1999 experiments}

Most of the East Lobe Lake Bonney experiments were performed with water from a depth of $22 \mathrm{~m}$, identified from the hydrography as the depth where the denitrification zone would be expected to occur in a conventional suboxic water column, i.e. the depth analogous to $16 \mathrm{~m}$ in the West Lobe. The designated comparison depth in ELB, where an active bacterial community has been consistently detected above the chemocline, was $19 \mathrm{~m}$. The gradients associated with the chemocline were extremely sharp in this region, and slight differences in sampling depth affected the initial conditions, making exact duplication of experiments difficult (see below).

Effect of chelators. In the short ( 2 to $3 \mathrm{~h}$ ) incubations performed in 1999 on 22 m water, very little activity was detected in any treatment. The addition of chelators (Expt 5, $1 \mu \mathrm{M}$ DFB and $0.75 \mu \mathrm{M}$ DTPA) initially had no significant effect on thymidine incorporation by the indigenous bacteria but appeared significantly to enhance their thymidine incorporation rate relative to that in the control on Day 6 (Fig. 3).

In the parallel treatments, which received live bacteria, the treatment that received $\mathrm{CB}$ alone was the only treatment to show activity initially and after $6 \mathrm{~d}$ (Expt 5). However, the initial thymidine incorporation rates by $\mathrm{CB}$ treatments that received chelators were all less than by the treatment that received live bacteria alone, and thymidine incorporation rates were not significantly enhanced after $6 \mathrm{~d}$. Note that the initial microbial activity of the added cell treatment was lower than in the WLB experiments (200 vs $1000 \mathrm{dpm}$ $\mathrm{h}^{-1}$ ), even though these incubations received the same specific activity of tracer and only a factor of 2 lower concentration of $\mathrm{CB}$ (enumerated by IIF in samples collected at the initial time point). 
Effect of lake water dilution (with DTPA and acetate). Dilution with either MQ or ALW was used to investigate the independent effects of salinity and metal concentration in ELB 19 and 22 m water. Water from $19 \mathrm{~m}$ was used for Expt 6 in order to provide a contrast for comparing activity above and below the chemocline in the East Lobe. Expt 6A detected activity in both Day 0 and Day 4 samples of the indigenous community collected at $19 \mathrm{~m}$ with no additions and in the $50 \%$ dilution after $4 \mathrm{~d}$ (Fig. 3). All of the chelator and acetate additions appeared to inhibit activity by Day 1 (relative to the control), and the treatments did not significantly recover by Day 4. Activity in the indigenous controls at $19 \mathrm{~m}$ was significantly higher than that observed at $22 \mathrm{~m}$ (Expt 5), but this activity was not enhanced by dilution (Milli-Q or ALW) or by the addition of chelators or carbon substrate (acetate). As was seen in experiments with West Lobe waters, addition of CB to $19 \mathrm{~m}$ ELB water resulted in much higher levels of initial activity (Expt 6B) relative to uptake by the indigenous bacteria in the parallel treatments (Expt 6A). Comparison between activity in the $\mathrm{CB}$ treatments of Expts $6(19 \mathrm{~m})$ and $5(22 \mathrm{~m})$ indicated that the water at $19 \mathrm{~m}$ is less immediately toxic than that at $22 \mathrm{~m}$. Nonetheless, only 1 of the CB treatments showed growth over the $4 \mathrm{~d}$ incubation, in contrast to the response observed in West Lobe $16 \mathrm{~m}$ water (Expts 2 and 3; Fig. 2), suggesting that bacteria at this depth are stressed by some factor (but see below). The addition of acetate alone to both indigenous and added cells did not enhance thymidine incorporation rate, suggesting that organic carbon was not a limiting factor.

To test whether the addition of bacteria cultures to $19 \mathrm{~m}$ water enhanced activity as a result of the activity of the added cells themselves or due to the addition of conditioning agents (e.g. chelators) or carbon substrates present in the culture medium, culture filtrates $(2 \mathrm{ml}$, the same volume of cell culture that was added in CB additions) were added to treatments diluted with MQ. No positive response was observed compared to the parallel treatment diluted by $50 \%$ with $\mathrm{MQ}$ with $\mathrm{CB}$ added; i.e. filtrate alone had no effect.

Unfortunately, no CB-only treatment was included as part of Expt 6. Therefore, we cannot ascertain whether dilution increased the activity of $\mathrm{CB}$ above that which would have been detected in undiluted lake water. Replacing the salts, i.e. diluting with ALW instead of MQ had no effect on activity, as observed in WLB experiments.
East Lobe Lake Bonney 2000 experiments

In 2000, experiments were carried out for longer periods, both in terms of exposure to the treatment (up to $14 \mathrm{~d}$ ) and the duration of the thymidine incorporation rate measurements $(24 \mathrm{~h})$, and were performed under conditions that preserved the oxygen concentra-
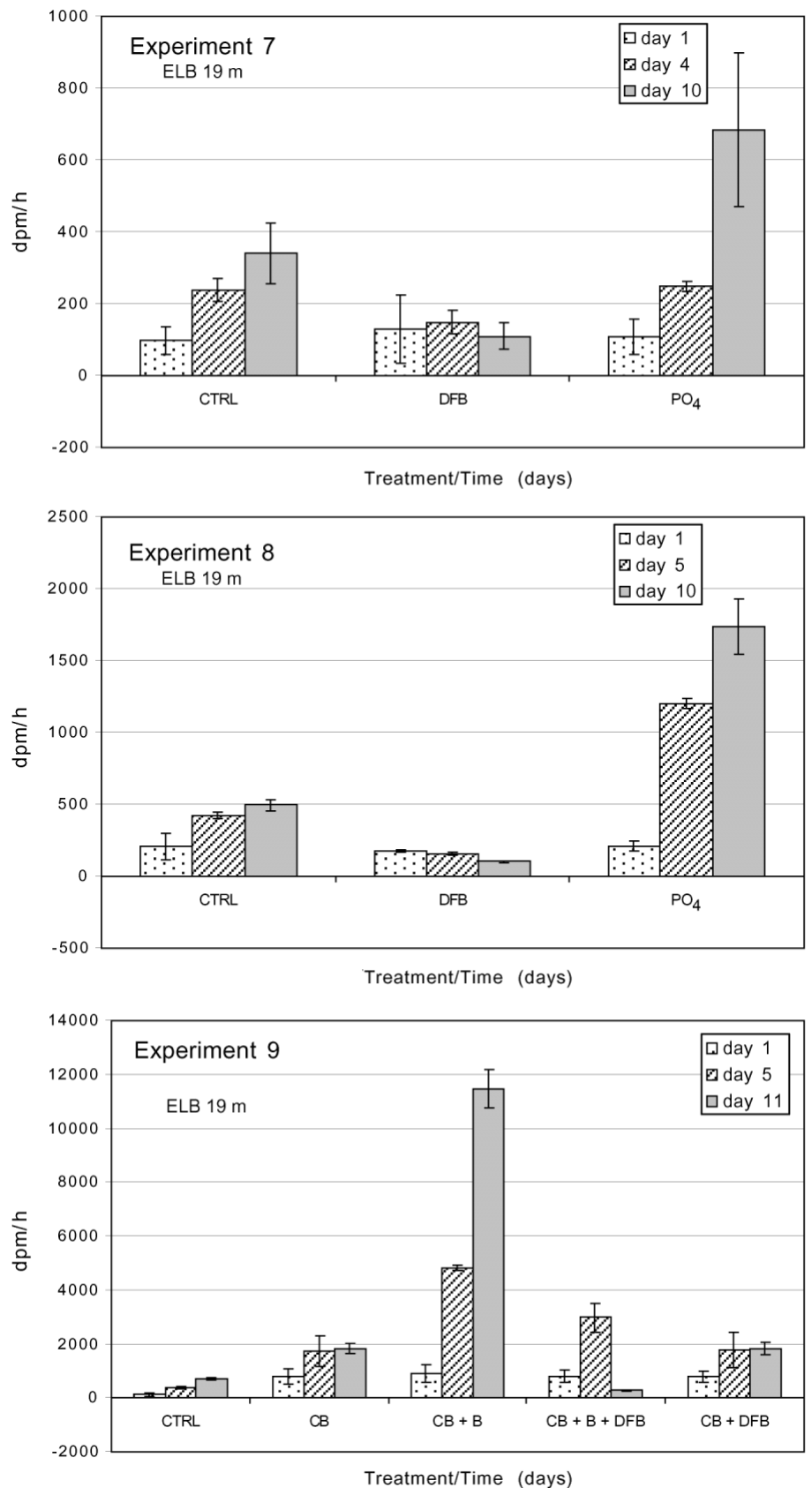

Fig. 4. East Lobe Lake Bonney (ELB) experiments in 2000 with $19 \mathrm{~m}$ water. Expt 7 (14 November 2000) and Expt 8 (20 November 2000), macronutrient (P) limitation. Expt 9 (14 November 2000), effect of organic carbon additions. DFB additions were $5 \mu \mathrm{M}$ 
tion of the sample during the thymidine incorporation rate measurements as well as during the bag incubation. Cells of the denitrifying strains WLB20 and ELB17 were grown as described previously, but were harvested by centrifugation and resuspended in minimal volumes of clean seawater before addition to the incubation bag, in order to minimize the addition of extra substrate or medium-conditioning molecules. The results of the ELB 2000 experiments are summarized in Table 3.

Macronutrient, chelator and organic carbon additions at $19 \mathrm{~m}$. Three experiments (Expts 7, 8 and 9) using water from $19 \mathrm{~m}$, at the top of the chemocline in ELB, verified the viability of microbial populations at that depth and investigated the effect of various additions on their activity. Activity and growth were detected in the controls in all 3 experiments (Fig. 4), in contrast to experiments in 1999, where activity but no growth was detected. This difference probably exists because the longer thymidine incubation times ( $24 \mathrm{~h}$ ) yielded greater sensitivity. Expts 7 and 8 indicated that phosphate might limit bacterial production above the chemocline. These 2 experiments were identical except that water for Expt 7 was collected with the pump on 14 November and water for Expt 8 was collected with a 51 Go-Flo bottle 1 wk later. The results were very similar, differing only in the magnitude of some treatments but not in the patterns. The indigenous community with no additions showed significant increase in thymidine incorporation over $10 \mathrm{~d}$, but the increase was significantly greater in the indigenous population that received a phosphate addition (Expts 7 and 8; Fig. 4). The addition of DFB appeared to inhibit bacterial activity over time when compared to controls. The difference in magnitude in the maximum rates detected (1700 vs $690 \mathrm{dpm} \mathrm{h}^{-1}$ ), as well as in the initial activity of the control treatment (200 vs $100 \mathrm{dpm} \mathrm{h}^{-1}$ ), may well be due to the different sampling methods.
The Go-Flo sample was integrated over a wider depth range than the pumped sample. Initial nitrite concentration for Expt 7 was $1.47 \mu \mathrm{M}$ and for Expt 8 was $0.40 \mu \mathrm{M}$, which indicates that water for Expt 7 was collected at a slightly greater depth than water for Expt 8 (Fig. 1). In Expt 9 (19 m), higher initial activity was observed in treatments containing added bacteria compared to the indigenous community, and this activity increased further between Days 2 and 5. However, sustained growth occurred only when bactopeptone was also added, suggesting that growth in the incubations became limited by available organic substrates as bacteria populations increased. This result contrasts with Expt 6B, in which acetate did not enhance growth of added cells, perhaps indicating that the cells may be limited by nutrients other than carbon present in bactopeptone, such as N or P. DFB had no effect when added with cultured bacteria but appeared to inhibit growth by Day 11, when peptone was added, suggesting that chelation of iron by DFB limited iron supply to actively growing bacteria.

Phosphate and chelator effects at $22 \mathrm{~m}$. Three experiments at 22 and $25 \mathrm{~m}$ (Expts 10, 11 and 12) tested the effect of several chelators and phosphate additions. The highest activity in these 3 experiments, about $140 \mathrm{dpm} \mathrm{h}^{-1}$, was at least 80 -fold lower than the highest activity, nearly $12000 \mathrm{dpm} \mathrm{h}^{-1}$, at $19 \mathrm{~m}$ (note scale change between Expts 9 and 10). In Expt 10, activity increased over the $10 \mathrm{~d}$ incubation, but scatter among replicates in the control precluded detecting any statistically significant trend (Fig. 5). The control, DTPA and phosphate incubations all showed increased activity (activity on Day 10 was greater than initial activity) but the treatments were not significantly different from the controls. Addition of DFB appeared to inhibit growth by Day 10, similar to the response seen at $19 \mathrm{~m}$ (see above). In contrast, addition of DDC significantly decreased bacterial

Table 3. Summary of thymidine incorporation experimental results in ELB in $2000 .+$ : activity; ++: growth; -: inhibition; -/++: recovery; gray cells: treatment was not included in the experiment; CTRL: control, no additions; DFB: desferrioxamine B; DTPA: diethylenetriaminepentaacetic acid; EDTA: ethylenediaminetetraacetic acid; DDC: diethyldithio-carbamate; HA: humic acid; CB: cultured bacteria; $\mathrm{B}$ : bactopeptone; $\mathrm{PO}_{4}$ : phosphate

\begin{tabular}{|c|c|c|c|c|c|c|c|c|c|c|c|c|c|c|}
\hline $\begin{array}{l}\text { Depth } \\
\text { (m) }\end{array}$ & Expt & $\begin{array}{l}\text { Treatment } \\
\text { CTRL }\end{array}$ & DFB & DTPA & EDTA & DDC & $\mathrm{CB}$ & $\mathrm{DFB}+\mathrm{CB}$ & $\mathrm{HA}+\mathrm{CB}$ & $\mathrm{CB}+\mathrm{B}$ & $\begin{array}{c}\mathrm{DFB}+\mathrm{CB} \\
+\mathrm{B}\end{array}$ & $\begin{array}{c}\mathrm{DDC}+\mathrm{CB} \\
+\mathrm{B}\end{array}$ & $\begin{array}{c}\mathrm{HA}+\mathrm{CB} \\
+\mathrm{B}\end{array}$ & $\mathrm{PO}_{4}$ \\
\hline 19 & 7 & ++ & + & & & & & & & & & & & ++ \\
\hline 19 & 8 & ++ & + & & & & & & & & & & & ++ \\
\hline 19 & 9 & ++ & & & & & ++ & ++ & & & ++ & & & \\
\hline 22 & 10 & ++ & + & ++ & & $-/++$ & & & & & & & & ++ \\
\hline 22 & 11 & ++ & & ++ & ++ & + & & & & & & & & \\
\hline 25 & 12 & + & & ++ & $-/++$ & & & & & & & & & \\
\hline 22 & 13 & ++ & & & & & ++ & ++ & & $-/++$ & $-/++$ & & & \\
\hline 22 & 14 & + & + & & & & & & + & & & $-/++$ & $-/++$ & \\
\hline
\end{tabular}


activity on Day 1 relative to other treatments and the controls, but the indigenous population appeared to recover partially over the next $10 \mathrm{~d}$. The apparent inhibitory effect of DDC on growth of indigenous bacteria was confirmed in later experiments (see below).

Expts 11 and 12 were conducted to evaluate whether chelator concentrations in the above treatments may have been insufficient to alleviate metal toxicity. Water was collected from $22 \mathrm{~m}$ (Expt 11; Fig. 5) and 25 m (Expt 12; Fig. 5) using a Go-Flo bottle instead of the peristaltic pump tubing. As a consequence, these samples were integrated over a larger depth range (about $0.8 \mathrm{~m}$ ), centered upon the target depth, than the previous experiments, in which samples were pumped from a narrow depth range. This distinction is important here because the sharply defined density/chemistry gradients with depth likely will have a profound effect on the bioactive constituents responsible for the low activity of the indigenous bacteria. The control at $22 \mathrm{~m}$ showed net growth over the $10 \mathrm{~d}$ experiment, although activities were substantially lower than in Expt 10, which used water collected by pumping. Activities in the control at $25 \mathrm{~m}$ were lower still. Additions of high concentrations of EDTA $(0.1,1.0 \mathrm{mM})$ and DTPA $(0.1 \mathrm{mM})$ to the $22 \mathrm{~m}$ waters did not enhance activity but appeared to diminish the increase in activity over time relative to the control. Addition of $0.1 \mathrm{mM}$ DDC had a strong negative effect on thymidine incorporation rate. Addition of $1 \mathrm{mM}$ EDTA and $0.1 \mathrm{mM}$ DTPA to $25 \mathrm{~m}$ waters did not enhance thymidine uptake relative to the control (Expt 12; Fig. 5). Although there is some indication of increased activity over time in these treatments, it is due more to the initial inhibitory effect of the ligands in these treatments than to any real enhancement of activity. In other words, the apparent 'growth' was simply recovery back up to the level of the no amendment control.

The very high chelator concentrations used in these 2 experiments were intended to overwhelm all metal activities to remove toxicity, but they did not increase thymidine incorporation rates substantially compared to the control treatment over the course of the incubation and, in fact, may have been inhibitory at $22 \mathrm{~m}$ (Fig. 5).

Effect of organic carbon, iron and chelators at $22 \mathrm{~m}$. The last 2 experiments at $22 \mathrm{~m}$ included a few additional chelator treatments as well as the addition of organic carbon and live bacteria (Fig. 6). The highest activity in these experi- ments, less than $120 \mathrm{dpm} \mathrm{h}^{-1}$ even with the addition of CB, was similar to that observed in Expt 10 and much lower than the highest activity at $19 \mathrm{~m}$ (compare Expts 9 with 13 and 14 ; Figs. 3 \& 6). Activity was detected initially in the indigenous community in both experiments. In Expt 13, growth occurred between Days 1
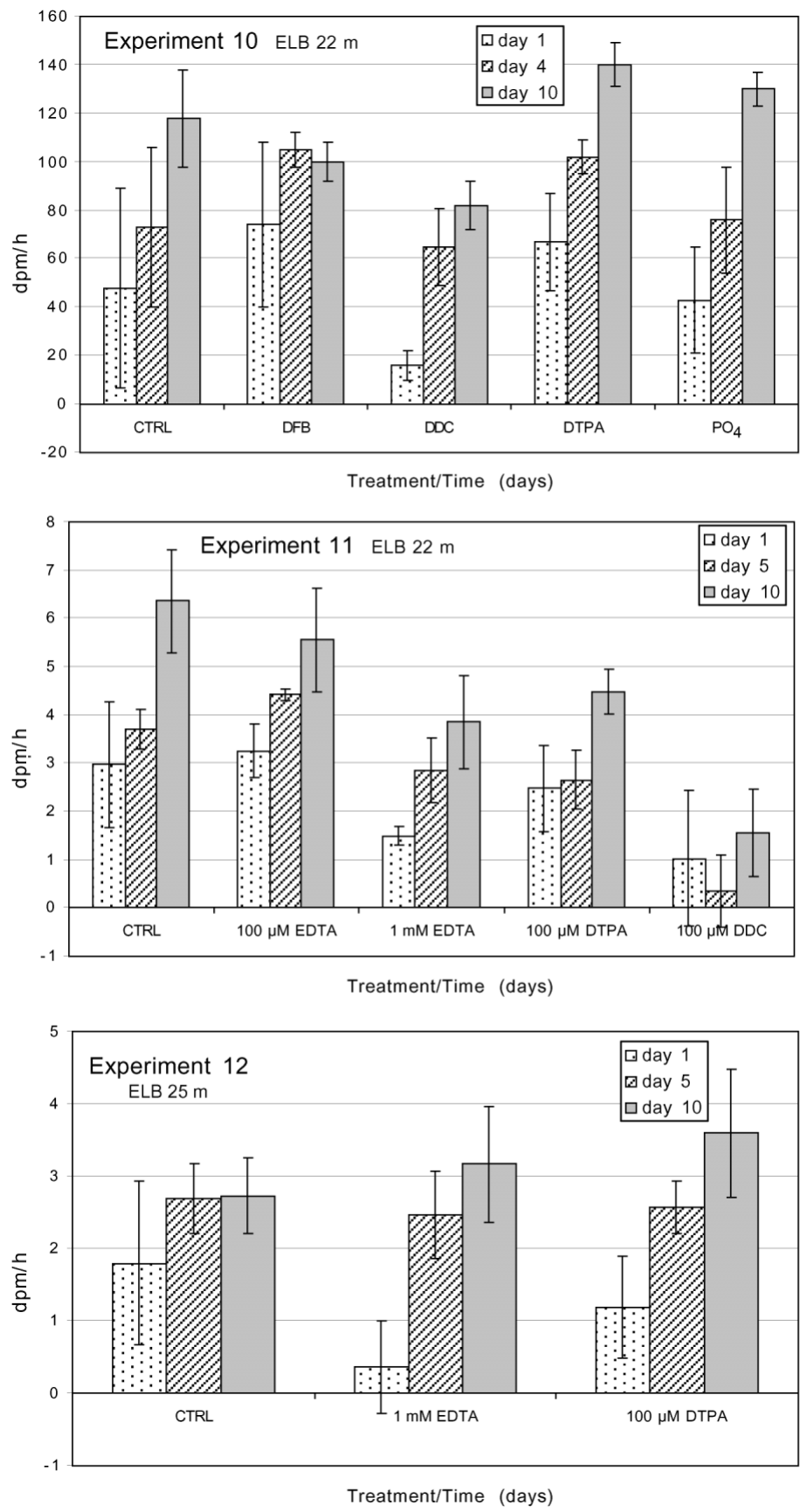

Fig. 5. East Lobe Lake Bonney (ELB) experiments in 2000. Expt 10 (14 November 2000; $22 \mathrm{~m}$ ), phosphate and iron effects. DFB additions were $5 \mu \mathrm{M}$, DDC additions were $10 \mathrm{mM}$, DTPA additions were $10 \mu \mathrm{M}$. Expts 11 (30 November 2000; $22 \mathrm{~m}$ ) and 12 (30 November $2000 ; 25 \mathrm{~m})$, effects of extremely high chelator concentrations 

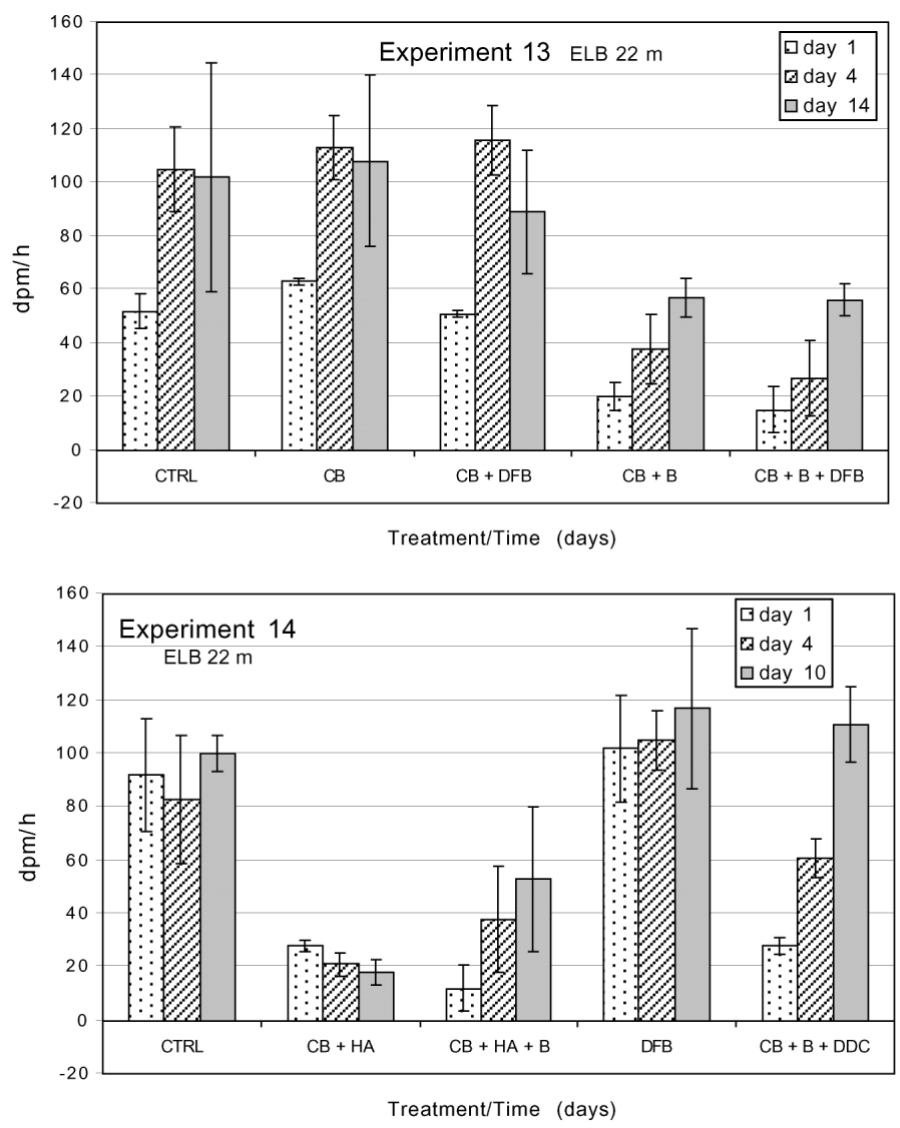

Fig. 6. East Lobe Lake Bonney (ELB) experiments in 2000 with $22 \mathrm{~m}$ water. Expts 13 (20 November 2000) and 14 (22 November 2000), effect of organic carbon and chelators. DFB additions were $5 \mu \mathrm{M}$ and DDC additions were $10 \mu \mathrm{M}$

and 4, and that appeared to represent a recovery back to initial levels observed in Expt 14. Notably, treatments with the addition of $\mathrm{CB}$, alone or with $\mathrm{DFB}$, yielded the same activity as measured in the indigenous community controls, whereas at 19 m (Expt 9), CB treatments always showed enhanced initial activity even when activity did not increase throughout the incubation. This finding perhaps suggests that the physiology of the added bacteria was not tuned adequately to in situ conditions at $22 \mathrm{~m}$ and that the bulk of the measured response in these treatments was attributable to the indigenous bacteria. Paradoxically, the addition of bactopeptone appeared to decrease activity relative to the control; i.e. an inhibitory effect contrasting with the enhancement observed in $19 \mathrm{~m}$ water. Bactopeptone was inhibitory at the initial time point when added in all combinations - with humic acid, with DDC, with DFB or alone to CB (Expts 13 and 14; Fig. 6). Addition of HA to a bacterially amended treatment strongly inhibited activity throughout the $10 \mathrm{~d}$ experiment. The added peptone treatments appear to show active recovery over the $14 \mathrm{~d}$ incubation, but activities never exceeded that in the control by the end of the experiment. The addition of DFB had no effect on the activity of added CB at $22 \mathrm{~m}$, as was observed for $19 \mathrm{~m}$ in Expt 10.

\section{DISCUSSION}

The West Lobe experiments were conducted in 1999, when all the incubations were $2 \mathrm{~h}$. Previous reports consistently found bacterial activity at this depth based upon $24 \mathrm{~h}$ uptake incubations, so we attribute our failure to detect activity in most of the indigenous community treatments to a lack of sensitivity resulting from our short incubation periods. The shorter interval used here was chosen to minimize any potential effects associated with exposure to air of samples withdrawn from the incubation bags. Nevertheless, the treatments containing added bacteria demonstrate that WLB water supports bacterial activity and that dilution with MQ enhances this activity. DTPA additions to WLB water enhanced activity of added cells, suggesting it may have affected metal speciation favorably. However, the effect was not additive (DTPA did not enhance activity in the diluted treatments). The remaining chelator addition treatments showed no consistent enhancement of activity.

From the 1999 experiments in ELB, we concluded that the hypolimnion of the ELB is not, in fact, a dead zone. Activity was detected both in the indigenous community, albeit at very low levels, and in the $\mathrm{CB}$ treatments. However, there were no clear, reproducible indications that any of the treatments significantly increased the activity of the indigenous population, or of added live cells, even after exposure to the treatment for up to $6 \mathrm{~d}$. Activity was greater at 19 than at $22 \mathrm{~m}$, as expected, and added cells showed higher activity at $19 \mathrm{~m}$, implying some toxic effect on their metabolism in $22 \mathrm{~m}$ water. Experiments in both 1999 and 2000, designed to test the response of the microbes in ELB to changes in bioactive metal availability, generally failed to elicit a significant response. This result implies either that metals are not the primary control on activity or that a more specific investigation of speciation of individual metals and metal-biota interactions is required to resolve the mystery.

There are several reports of trace element distributions in the lakes of the McMurdo Dry Valleys (Boswell et al. 1967a,b, Weand et al. 1976, Masuda et al. 1982, Green et al. 1986, 1988, 1989). The early data available for Lake Bonney (Boswell et al. 1967a,b) were reported for an unspecified location in the deep water of the lake, so it is impossible to make any direct comparisons. The concentrations reported in 
1967 generally are within 1 order of magnitude of those measured in 1999 and 2000. Weand et al. (1976) sampled at sites very near the east end of the East Lobe, focusing on the contribution of melt water streams; therefore, although these data are consistent with the increasing metal concentrations in the hypolimnion, none of these reports is directly applicable to our sites. Metal concentrations are sufficiently low in the surface layer that they may be in the range capable of limiting phytoplankton production, but their concentrations increase dramatically below the chemocline (Table 2; author's unpubl.). Most transition elements increase in solubility in reducing conditions, and the main source of these elements may be molecular diffusion out of the concentrated brine pools that fill the deepest regions of both lobes of Lake Bonney (Lyons et al. 2000). The highest concentrations of $\mathrm{Cd}, \mathrm{Pb}, \mathrm{Ni}$ and $\mathrm{Zn}$ occur in the East Lobe at $25 \mathrm{~m}$, while $\mathrm{Co}$ and $\mathrm{Cu}$ are highest in the West Lobe at $35 \mathrm{~m}$ (Table 2). The major ion concentrations in Lake Bonney show the same pattern of surface depletion and deep-water enrichment. The surface water is replenished by annual seasonal melt water stream flow, while the deep water may not have been renewed or fully mixed since the last evaporative episode ended some 900 to 1200 yr ago (Lyons et al. 2000). Melt water, salts and metals continue to enter the West Lobe of Lake Bonney from the snout of the Taylor Glacier, but the deep water of the East Lobe is saltier than that of the West Lobe, albeit with different elemental ratios (Table 1).

P-limitation appears to be a general feature of the epilimnion of Lake Bonney. Dore \& Priscu (2001) showed clear evidence that $\mathrm{CO}_{2}$ fixation by phytoplankton is stimulated by addition of inorganic phosphate for both lobes of Lake Bonney. Alkaline phosphatase activity was associated with the bacterial size fraction, which provides indirect evidence for P-limitation of bacteria. Lake Bonney's history of repeated evaporation, leading to selective precipitation of phosphate minerals in the brine, is suggested as the ultimate reason for phosphate depletion in Lake Bonney (Lyons et al. 2000, Dore \& Priscu 2001).

There is significant bacterial activity above the chemocline in both East and West Lobes of Lake Bonney that continues into the sub-oxic waters of the West Lobe, where denitrification is observed. Water below the chemocline in the East Lobe supports only very low, but analytically significant, rates of thymidine incorporation, and the geochemical evidence is that denitrification is lacking there. It is curious, then, that a maximum in bacterial numbers is often observed at $25 \mathrm{~m}$ in the East Lobe, well below the maximum in bacterial production at 12 to $15 \mathrm{~m}$ (Takacs \& Priscu 1998). It was suggested (Ward et al.
1993) that the cell abundance maximum might be due to a dramatic increase in the abundance of nitrifiers at that depth, autotrophs which might contribute to biomass but not to thymidine incorporation. The maximum in nitrifier abundance, however, is generally shallower (12 to $15 \mathrm{~m}$ ) and 3 orders of magnitude or so smaller than the total bacterial abundance at that depth (Voytek et al. 1998). Takacs \& Priscu (1998) detected bacterial production in 5 out of 30 measurements below $20 \mathrm{~m}$ in ELB, and in 10 out of 16 measurements at $20 \mathrm{~m}$, in their $4 \mathrm{yr}$ study. The production rates were so low, however, that specific activity (uptake cell ${ }^{-1} \mathrm{~d}^{-1}$ ) was indistinguishable from 0 in all 46 measurements. This results from the mysterious biomass maximum - high numbers of nearly inactive cells - at $25 \mathrm{~m}$.

The imperfect suite of chemical tools used here to manipulate transition metal speciation provided no clear indication that metal toxicity (or metal limitation) could explain the lack of activity below the chemocline in the East Lobe. Bacteria isolated from the lake and cultured under optimal conditions did not grow when added to $22 \mathrm{~m}$ water, while the indigenous population showed low-level but non-0 rates of thymidine uptake. The implication is that the time frame for adaptation to in situ conditions exceeded the $2 \mathrm{wk}$ duration of our experiments. It might be reasonable to assume that adaptations by the indigenous populations to the altered chemical conditions in our experiments might also require long time frames before changes become expressed as increased rates of thymidine incorporation. As a consequence, it is unclear whether these experiments can rule out metal stress as the cause for low activity in these waters.

There also may be some question about the suitability of thymidine as a tracer for bacterial activity in these waters. Although thymidine incorporation is generally accepted as a measure of heterotrophic bacterial activity, there are several groups of bacteria whose activity is not adequately quantified by this method (Winding 1992). Obligate anaerobes (e.g. sulfate reducers, fermenters) and chemoautotrophs generally do not assimilate thymidine, and thus, communities in which these groups contribute a major portion of the biomass will not be reliably assayed with this method. Lake Bonney contains no sulfide, although sulfate is a major ion in the deep water, so anaerobic metabolism by conventional sulfate reducers and fermenters is not likely to be important here. Metalreducing bacteria, some of them obligate anaerobes, may be present; however, little is known of their thymidine incorporation capabilities. There is evidence of a significant chemoautotrophic nitrifying assemblage near the chemocline (Voytek et al. 1999) 
but the absolute numbers of these cells is only in the order of 0.1 to $1 \%$ of the total bacterial abundances (Voytek et al. 1998). Thus, it seems unlikely that the composition of the bacterial assemblage in the East Lobe would cause an artificially low estimate of bacterial production in terms of thymidine incorporation. In any case, the long metabolic response times indicated in our experiments suggests that other, more direct metabolic assays (e.g. vital stains such as 5cyano-2,3-ditolyl tetrazolium chloride [CTC] in aerobic conditions; Smith et al. 1994) may be useful in probing the bacterial biomass for indications of viability and response to manipulations of chemical conditions.

\section{CONCLUSIONS}

A large number of experiments was performed in a manner that allowed independent replication of treatments: water collected from the same depth but on different days (and therefore, handled and subjected to manipulations on different days) was subjected to the same treatments in different combinations. The results described above lead to the following conclusions, which are summarized in answer to several questions that informed our experimental design.

(1) Is the suboxic water below chemocline depths in ELB toxic to bacterial life? Yes. The very low activity levels imply that the water was indeed toxic, but not so completely as to preclude activity altogether. Activity was detected in the control treatments in each experiment but decreased with increasing proximity to the remnant bottom waters that had been exposed subaerially in the recent geologic past. Ionic concentrations in the deep water have been interpreted to result from diffusion from the high concentrations in the brine pool, combined with differential precipitation (Wilson 1979, Lyons et al. 2000). Our results indicate that this deep water is the direct source of the substances responsible for bacterial inhibition in the East Lobe. These data imply that there might yet be some treatment that could allow the indigenous cells to recover from this toxicity and grow. More direct, cellular indicators for the shift in cell metabolism are needed to better address the question of whether metal stress is responsible for the difference in microbial activities between the East and West Lobes of Lake Bonney.

(2) Was bacterial growth in ELB limited by toxicity of bioactive transition metals whose availability could be reduced by chelation? No, at least over the time frame of our experiments. Additions of chelators alone (DFB, DDC, EDTA) to the indigenous community did not enhance activity relative to the controls, with perhaps one exception. The DTPA treatment in Expt 10 showed activity comparable to that observed in the phosphate addition treatment, but neither exceeded the activity in the control by the end of the experiment. In general, the addition of the general synthetic chelators EDTA and DTPA had little or no enhancement effect on thymidine uptake in these incubations, with or without added cultured bacteria. Addition of the specific iron chelator DFB had an inhibitory effect at both 19 and $22 \mathrm{~m}$ depth. Thus, if metal toxicity is a factor inhibiting bacterial activity in ELB, we were unable to remove its effect with this suite of chelator additions over the duration of these experiments.

Even so, these experiments do not rule out metal inhibition of bacteria in these waters. The absence of enhanced activity by the addition of cultured bacteria to ELB deep water (with one exception, Expt 5), even though they were isolated from the same lake, demonstrates the need for cells to acclimate to in situ conditions. It is possible then that the duration of our experiments was insufficient to allow the indigenous population to 'recover', which might require several weeks at these low growth rates. Alternatively, it is possible that the chelators we employed did not bind the toxic components sufficiently to remove their toxicity or by doing so, the availability of other required metals became limiting. In that case, metal toxicity could still be an important factor, but one that we were unable to alter with sufficient precision. Finally, the bacterial activity could be inhibited by metals that were not complexed by the chelators tested.

(3) Was growth limited by carbon substrate concentration? No. Addition of acetate, a labile carbon substrate, did not enhance activity. Bactopeptone additions produced inconsistent results. When bactopeptone did increase activity it cannot be determined which component was responsible, suggesting that P-limitation may be the underlying phenomenon, rather than C-limitation.

(4) Was growth limited by a nutrient element? Yes, at $19 \mathrm{~m}$. Phosphate addition consistently enhanced growth in the indigenous population at $19 \mathrm{~m}$ in ELB (Expts 7 and 8). In all 3 experiments at $19 \mathrm{~m}$, growth was detected in the control (perhaps due to removal of grazers in this slightly oxygenated water) but phosphate addition caused a significantly greater increased thymidine incorporation rate. Thus, is it clear that bacterial production in the surface layer was limited by phosphate. However, phosphate did not clearly enhance growth or activity in deeper waters.

Acknowledgements. We thank Ben Hunt for collecting the CTD data and the Crary Analytical Laboratory team for the nutrient analyses. This research was supported by OPP-NSF grants to B.B.W. and M.L.W. 


\section{LITERATURE CITED}

Bell RT (1993) Estimating production of heterotrophic bacterioplankton via incorporation of tritiated thymidine. In: Kemp PF, Sherr BF, Sherr EB, Cole JC (eds) Handbook of methods in aquatic microbial ecology. CRC Press, Boca Raton, FL, p 495-503

Boswell CR, Brooks RR, Wilson AT (1967a) Some trace elements in lakes of McMurdo Oasis, Antarctica. Geochim Cosmochim Acta 31:731-736

Boswell CR, Brooks RR, Wilson AT (1967b) Trace element content of Antarctic lakes. Nature 213:167-168

Broenkow WW, Cline JD (1969) Colorimetric determination of dissolved oxygen at low concentrations. Limnol Oceanogr 14:450-454

Bruland KW, Knauer GA, Martin JH (1979) Sampling and analytical methods for the determination of copper, cadmium, zinc and nickel at the nanogram per liter level in seawater. Anal Chim Acta 105:223-245

Coyne M, Arundkumari A, Averill B, Tiedje JM (1989) Immunological identification and distribution of dissimilatory heme cd1 and nonheme copper nitrite reductases in denitrifying bacteria. Appl Environ Microbiol 55:2924-2931

Dore JE, Priscu JC (2001) Phytoplankton phosphorus deficiency and alkaline phosphatase activity in the McMurdo Dry Valley lakes, Antarctica. Limnol Oceanogr 46: 1331-1346

Granger J, Price NM (1999) The importance of siderophores in iron nutrition of heterotrophic marine bacteria. Limnol Oceanogr 44:541-555

Green WJ, Canfield DE, Lee GF, Jones RA (1986) Mn, Fe, Cu and $\mathrm{Cd}$ distributions and residence time in closed basin Lake Vanda (Wright Valley, Antarctica). Hydrobiology 134:237-248

Green WJ, Angle MP, Chave KE (1988) The geochemistry of Antarctic streams and their role in the evolution of 4 lakes of the McMurdo Dry Valleys. Geochim Cosmochim Acta 52:1265-1274

Green WJ, Ferdelman TG, Canfield DE (1989) Metal dynamics in Lake Vanda (Wright Valley, Antarctica). Chem Geol 76:84-94

Hobbie JE, Daley RJ, Jasper S (1977) Use of Nuclepore filters for counting bacteria by epifluorescence microscopy. Appl Environ Microbiol 33:1225-1228

Lyons WB, Tyler SW, Wharton RA Jr, McKnight DM, Vaughn BH (1998) A late holocene desiccation of Lake Hoare and Lake Fryxell, McMurdo Dry Valleys, Antarctica. Antarct Sci 10:247-256

Lyons WB, Fountain A, Doran P, Priscu JC, Neumann K, Welch KA (2000) Importance of landscape position and legacy: the evolution of the lakes in Taylor Valley, Antarctica. Freshw Biol 43:3555-3567

Martinez JS, Haygood MG, Butler A (2001) Identification of a natural desferrioxamine siderophore produced by a marine bacterium. Limnol Oceanogr 46:420-424

Masuda N, Nishimura M, Torii T (1982) Pathway and distribution of trace elements in Lake Vanda, Antarctica. Nature 298:154-156

Parsons TR, Maita Y, Lalli CM (1984) A manual of chemical

Editorial responsibility: James Hollibaugh,

Athens, Georgia, USA and biological methods for seawater analysis. Pergamon Press, Oxford

Price NM, Harrison JG, Herring JG, Hudson RJ, Nirel PMV, Palenik B, Morel FMM (1988/1989) Preparation and chemistry of the artificial algal culture medium Aquil. Biol Oceanogr 6:443-461

Priscu JC (1995) Phytoplankton nutrient deficiency in lakes of the McMurdo Dry Valleys, Antarctica. Freshw Biol 34: $215-227$

Priscu JC (1997) The biogeochemistry of nitrous oxide in permanently ice-covered lakes of the McMurdo Dry Valleys, Antarctica. Global Change Biol 3:301-315

Priscu JC, Spigel RH (1998) Physical limnology of the McMurdo Dry Valleys lakes. In: Priscu JC (ed) Ecosystem dynamics in a polar desert: the McMurdo Dry Valleys, Antarctica. Antarctic Research Series, Vol 72. American Geophysical Union, Washington, DC, p 153-188

Priscu JC, Downes MT, McKay CP (1996) Extreme supersaturation of nitrous oxide in a poorly ventilated Antarctic lake. Limnol Oceanogr 41:1544-1551

Sillanpaa M, Aimo O (1996) Assessing the impact of complexation by EDTA and DTPA on heavy metal toxicity using Microtox bioassay. Chemosphere 32:1485-1497

Smith JJ, Howington JP, McFeters GA (1994) Survival, physiological response and recovery of enteric bacteria exposed to a polar marine environment. Appl Environ Microbiol 60:2977-2984

Takacs CD, Priscu JC (1998) Bacterioplankton dynamics in the McMurdo Dry Valley lakes, Antarctica: production and biomass loss over 4 seasons. Microb Ecol 36:239-250

Voytek MA, Ward BB, Priscu JC (1998) The abundance of ammonium-oxidizing bacteria in Lake Bonney, Antarctica determined by immunofluorescence, PCR and in situ hybridization. In: Priscu JC (ed) Ecosystem dynamics in a polar desert: the McMurdo Dry Valleys, Antarctica. Antarctic Research Series, Vol 72. American Geophysical Union, Washington, DC, p 217-228

Voytek MA, Priscu JC, Ward BB (1999) The distribution and relative abundance of ammonia-oxidizing bacteria in lakes of the McMurdo Dry Valley, Antarctica. Hydrobiology 401:113-130

Ward BB, Carlucci AF (1985) Marine ammonium- and nitriteoxidizing bacteria: serological diversity determined by immunofluorescence in culture and in the environment. Appl Environ Microbiol 50:194-201

Ward BB, Priscu JC (1997) Detection and characterization of denitrifying bacteria from a permanently ice-covered Antarctic lake. Hydrobiology 347:57-68

Ward BB, Cockroft AJ, Priscu JC (1993) Nitrifying and denitrifying bacteria in Lake Bonney. Antarct J US 1993: $240-242$

Weand BL, Hoehn RC, Parker BC (1976) Trace element distributions in an Antarctic meromictic lake. Hydrobiol Bull 10:104-114

Wilson AT (1979) Geochemical problems of the Antarctic dry areas. Nature 280:205-208

Winding A (1992) $\left[{ }^{3} \mathrm{H}\right]$-thymidine incorporation to estimate growth rates of anaerobic bacterial strains. Appl Environ Microbiol 58:2660-2662

Submitted: July 29, 2002; Accepted: November 21, 2002

Proofs received from author(s): January 21, 2003 